Черкасова Татьяна Владимировна

кандидат социологических наук, доцент, доцент кафедры социальной работы Мордовского государственного университета им. Н.П. Огарева

\section{МНОГООБРАЗИЕ ФЕНОМЕНА РОДИТЕЛЬСТВА}

\section{Аннотация:}

Актуальность темы родительства обусловлена нарушением и невыполнением многими родителями свочх прав и обязанностей, что приводит к неблагополучному положению детей в России. В статье акцентируется внимание на кризисном состоянии института родительства, которое во многом определяет кризис семьи в России. В работе содержится комплексное и системное рассмотрение фе номена родительства в различных его проявлениях и аспектах: социальный институт, процесс социализации и адаптации человека к новому статусу родителя, важный период в жизни, социальный статус, особое состояние сознания, совокупность действий по достижению определенной родительской иели. Детальное изучение феномена и института родительства важно для разработки и реализации эффективной семейно-демографической политики в Российской Федерации.

Ключевые слова:

родительство, детство, социальный инсти mут, период, процесс, состояние, статус, деятельност
Cherkasova Tatiana Vladimirovna

PhD in Social Science, Assistant Professor, Social Work Department, Ogarev Mordovian State University

THE DIVERSITY OF THE PHENOMENON OF PARENTHOOD

Summary:

The relevance of the parenthood issue is due to violation and non-fulfillment of the parental rights and obligations by many parents. This leads to the situation of disadvantaged children in Russia. The author focuses on the crisis state of the institution of parenthood, which in many terms determines the crisis of the family in this country. The article provides a holistic and systematic consideration of the phenomenon of parenthood in its various manifestations and aspects. They include the social institution, the process of socialization and adaptation of a person to a new status of the parent, an important period in life, a social status, a special state of consciousness, a set of actions to achieve a particular parental goal. A detailed study of the phenomenon and the institution of parenthood is extremely important for the development and implementation of an effective family and demographic policy in the Russian Federation.

Keywords: parenthood, childhood, social institution, period, process, state, status, activity.

Безответственное родительство стало актуальной проблемой для современного российского общества, что подтверждается сведениями о неблагополучном положении детей в России. В частности, Россия занимает первое место в Европе по количеству самоубийств среди детей и подростков, первое место в мире по числу детей, брошенных родителями, и по числу курящих детей (по данным информационно-новостного онлайн-издания Санкт-Петербурга MR7.ru).

Согласно официальным отчетам уполномоченного при Президенте РФ по правам ребенка П.А. Астахова, численность детей, оставшихся без попечения родителей, в России остается весьма высокой, продолжает расти число преступлений, совершенных в отношении детей. Негативное отношение современных родителей к своим детям можно оценить и через распространенность такого преступления, как злостное уклонение от уплаты средств на содержание детей. По данным Судебного департамента при Верховном суде РФ, данное преступление занимает второе место по количеству лиц среди осужденных за все преступления против личности [1, с. 515]. Сложившаяся картина свидетельствует о необходимости укрепления института семьи, и в частности института родительства. Неблагоприятная ситуация с реализацией родительских прав и обязанностей требует тщательного изучения родительства и разработки соответствующих специальных программ по его поддержке.

Актуальность рассмотрения родительства в современных условиях связана также с проблемой ущемления прав самих родителей, их дискриминацией. В обществе происходит исключение родителей из публичного пространства, например инвалидов или представителей этнических меньшинств. Действительно, на улицах городов и в публикациях в СМИ редко встречаются взрослые, исполняющие роль родителей, появляющиеся с ребенком на руках. Совместный выход родителя и ребенка, особенно малолетнего, в какое-либо общественное место (например, появление их в общественном транспорте) крайне затруднен, воспринимается не совсем доброжелательно со стороны окружающих людей. В этом контексте можно говорить о социопространственной маргинализации родителей. Без содействия родителям в реализации их прав невозможно требовать от них полного выполнения их родительских обязанностей. 
Обращение к проблемам современных родителей требует прежде всего анализа и уточнения самого термина «родительство». Изучению данного понятия посвящены работы А.И. Антонова, С.И. Голода, Т.А. Гурко, И.С. Кона, Р.В. Овчаровой, Л.И. Савинова и др. Исследуя родительство в первую очередь как социокультурный и социально-психологический феномен, означенные авторы все же указывают, что родительство является и социальным институтом, тесно связанным с институтом семьи. Многогранное исследование трансформации института родительства содержится в работе Т.А. Гурко «Брак и родительство в России» [2]. В современной российской социологии семьи изучение родительства как социального института становится новым и перспективным направлением. Появляются даже исследования этнической специфики фуннццинирования института родительства [3]. Несомненно, институт родительства тесно связан с институтом семьи, является его частью, но может быть реализован и вне семьи. В частности, в современных российских реалиях распространена практика исполнения родительских прав и обязанностей родителем, проживающим отдельно от своего ребенка в случае распада семьи.

За рубежом складывалось представление о родительстве как о социокультурном феномене (работы М. Мид, Х. Дойч, К. Хорни, А. Рич, Н. Чодороу), который затем стал детальнее изучаться отдельно на примере отцовства и материнства. На рубеже XIX-XX вв. в западной науке «произошло окончательное разделение в трактовке термина "материнство" как социального института (motherhood) и как субъективного восприятия (mothering)» [4, с. 130]. В научных работах ученых стран ближнего зарубежья также присутствует анализ родительства как социального института. Так, И.А. Курило исследует социально-экономическую среду функционирования института родительства [5]. В работе С.Ю. Девятых институт родительства рассматривается через два предписываемых, поощряемых и контролируемых обществом социальных института: отцовства и материнства [6].

Родительство как социальный институт имеет право на существование, поскольку у общества есть насущная потребность в нем. Возникновение родительства как социального института обусловлено необходимостью выживания, сохранения потомства, обеспечения его взросления [7, с. 70]. Придерживаясь позиции, что родительство является социальным институтом, определяем его как совокупность социальных норм и правил поведения родителей, в которых закреплены родительские права и обязанности, возникающие на основании такого юридического факта, как регистрация рождения или усыновления (опеки) ребенка. За невыполнение и недостаточно хорошее выполнение данных прав и обязанностей в стране действует система санкций, как моральных, так и закрепленных в законодательстве. Для усвоения и реализации ролей родителей существуют и действуют разнообразные институты и агенты: родственники, друзья, знакомые, соседи, ближайшее социальное окружение, специалисты учреждений (детских садов, общеобразовательных школ, детских поликлиник, СМИ, органов опеки и попечительства и т. д.). Действительно, для поддержания института родительства необходимо развитие смежных институтов, в частности инфраструктуры для воспитания детей и трудового законодательства, защищающего права работающих родителей [8].

Система норм родительства, характерных для традиционных семей, постепенно перестает действовать и применяться. Поэтому имеет место мнение, что традиционное родительство, как и традиционно понимаемое детство, может исчезнуть. Действительно, в современном обществе от человека в большей степени ожидается выполнение роли не родителя, а работника, производителя товаров и услуг. Для государства важно не каким родителем является гражданин, а какой он производитель общественно полезного продукта, насколько успешно самореализуется в профессии.

В научной литературе высказывается мнение, что неисполнение прежних норм родительства не означает исчезновения данного института вообще, а свидетельствует о появлении новых норм современного родительства. Приверженцы идеи «модернизации семьи и родительства» считают, что семья как социальный институт эволюционирует и сейчас разворачивается очередная стадия перехода от традиционалистских образцов материнства и отцовства к новым альтернативным формам [9, с. 96]. Данной точки зрения в анализе современной семьи придерживается ученый С.И. Голод.

Сторонники другого подхода указывают, что сам кризис семьи связан с исчезновением патриархальной модели родительства - этого важнейшего социального института, а новые модели выступают с этой точки зрения остатками деградации расширенной семьи, указывающими на отмирание семьи вообще, а не только «традиционной семьи» [10]. Но как бы ни оценивался процесс изменений, он, несомненно, сопровождается сложностями в адаптации к новым нормам родительства.

Рассмотрение родительства возможно и в других значениях.

1. Родительство можно представить как процесс социализации и адаптации человека к новому статусу - статусу родителя. Рассмотрение родительства как процесса предполагает анализ и обсуждение вопроса о выделении в нем различных этапов, а также соотношение их с различными 
стадиями жизни семьи. Однако сложно выработать однозначную позицию относительно выделения в родительстве каких-либо четких стадий его развития. Это связано с неопределенностью критериев разделения процесса адаптации родительства на стадии, с неясностью точек отсчета этих стадий. К примеру, это могут быть различные уровни развития ребенка либо разные степени усвоения самим взрослым норм родительства. В современной литературе можно встретить периодизацию родительства в зависимости от возраста детей. В частности, в психологии существует деление родительства на этапы в соответствии с особенностями возраста ребенка.

2. Многообразие проявлений феномена родительства позволяет рассматривать его и как особый период в жизни человека. Родительство - это один из этапов на пути становления человека «социальным» существом. Важным в жизни человека является переход от детства к родительству. Изучение этого периода требует выяснения вопроса о том, происходит этот переход напрямую или в нем присутствуют иные переходные стадии, например молодость, зрелость, супружество, или эти перечисленные стадии сменяют друг друга параллельно переходу от детства к родительству.

3. Родительство также можно изучать и как особый социальный статус человека. Приобретенный статус родителя может добавляться к уже существующим социальным ролям взрослого человека или заменять какие-то из прежних ролей, либо уже освоенная роль родителя может периодически обновляться, повторяться и дополняться. Осваиваемая роль родителя может реализовываться как в активной, так и в пассивной форме. По нашему мнению, современные родители зачастую выступают в зависимой и пассивной роли, ожидая помощи в воспитании детей от государства, школы, церкви, общества в целом. В условиях нарастания внешних угроз для развития ребенка от родителей требуется переход к более активным действиям, что, видимо, и является одной из черт ответственного родительства. Многие из современных родителей активно усваивают новые нормы родительства, ориентирование на поддержание индивидуальности, самостоятельности ребенка, развитие его талантов и внутреннего потенциала. Для этого самим родителям необходимо учиться и быть готовыми развивать в себе свои способности, творческие и иные умения, становясь примером для своих детей.

4. Родительство можно представить и как особое состояние сознания человека, имеющее главную особенность - покровительственность, контроль, наставление младших. Причем подобное состояние проявляется не только у людей в общении с их собственными детьми, но и у людей, не имеющих своих детей, но ведущих себя как родители, наставники с другими людьми, которых они воспринимают как младших, молодых, как «детей». Родительство - это проявление личных качеств взрослого человека.

5. Родительство также можно проанализировать как деятельность, совокупность действий по достижению определенной цели. При этом данная цель двояко направлена: во-первых, на развитие способностей ребенка, защиту его интересов, а во-вторых, на развитие личных качеств самого родителя. Родительство как деятельность представляет собой производство вклада, усилий, действий в здоровье, образование и материальное благополучие детей. По этим направлениям и следует осуществлять подготовку к родительству.

Таким образом, родительство - многогранный феномен, который можно рассматривать в различных аспектах: как социальный институт, процесс, период, состояние сознания, деятельность - или в каком-либо ином значении. Знания и результаты исследований по рассмотренным аспектам родительства должны лечь в основу разработки теоретических и практических занятий по подготовке молодежи к родительству. Пропаганда компетентного родительства, ориентированного на полноценное развитие детей, должна стать важным направлением семейно-демографической политики в России. Определяющим фрактором оказания семье материальной поддержки со стороны государства и общества должно стать добросовестное и компетентное выполнение родителями своей роли.

\section{Ссылки:}

1. Долголенко Т.В., Дорошенко В.Я. Злостное уклонение от уплаты средств на содержание детей или нетрудоспособных родителей: исторический, сравнительно-правовой анализ и судебная практика // Криминологический журнал Байкальского государственного университета экономики и права. 2015. Т. 9, № 3. С. 514-524.

2. Гурко Т.А. Брак и родительство в России : монография. М., 2008. 324 с.

3. Студитских В.В. Институт родителей и его влияние на развитие личности ребенка в традиционной культуре удмуртов // Ежегодник финно-угорских исследований. 2011. № 2. С. 96-102.

4. Мицюк Н.А. Проблема материнства в современных зарубежных исторических исследованиях // Вестник Тверского государственного университета. Серия «История». 2015. № 2. С. 124-134.

5. Курило І.О. Батьківство у демографрічному контексті: методологічні засади дослідження та деякі тенденції розвитку // Демографрія та соціальна економіка. 2016. № 3 (28). С. 11-25.

6. Девятых С.Ю. Феномен родительства: социально-психологический аспект : монография / под общ. ред. В.А. Сонина. Витебск, 2005. 104 с. 
7. Лущенко Э.М. Становление института родительства: фрилософский анализ // Позиция. Философские проблемы науки и техники. 2012. № 6 (6). С. 69-74.

8. Думанська В.П. Відповідальне батьківство: теоретичний аспект // Демографія та соціальна економіка. 2015. № 3 (25). C. $75-86$.

9. Сайфутдинова Г.Б. Основные тенденции развития семьи и родительства в современной России // Актуальные проблемы гуманитарных и естественных наук. 2017. № 3-2. С. 95-97.

10. Антонов А.И. Современная семья: два взгляда на одну проблему // Семья в России. 1999. № 1-2. С. 12-17.

\section{References:}

Antonov, Al 1999, 'Modern family: two views on one problem', Sem'ya v Rossii, no. 1-2, pp. 12-17, (in Russian).

Devyatykh, SYu \& Sonin, VA (ed.) 2005, The phenomenon of parenthood: the social and psychological aspect, monograph, Vitebsk, 104 p., (in Russian).

Dolgolenko, TV \& Doroshenko, VYa 2015, 'Malicious evasion of alimony to support children and disabled parents: historical, comparative law analysis and court practice', Kriminologicheskiy zhurnal Baykal'skogo gosudarstvennogo universiteta ekonomiki i prava, vol. 9, no. 3, pp. 514-524, https://doi.org/10.17150/1996-7756.2015.9(3).514-524.

Dumanskaya, VP 2015, 'Responsible paternity: a theoretical aspect', Demography and social economics, no. 3 (25), pp. 7586, (in Ukrainian).

Gurko, TA 2008, Marriage and parenthood in Russia, monograph, Moscow, 324 p., (in Russian).

Kurilo, IA 2016, 'Paternity in the demographic context: the methodological basis of the study and several development trends', Demography and social economics, no. 3 (28), pp. 11-25, (in Ukrainian).

Lushchenko, EM 2012, 'The formation of the institution of parenthood: a philosophical analysis', Pozitsiya. Filosofskiye problemy nauki i tekhniki, no. 6 (6), pp. 69-74, (in Russian).

Mitsyuk, NA 2015, 'The problem of motherhood in contemporary foreign historical research', Vestnik Tverskogo gosudarstvennogo universiteta. Seriya "Istoriya", no. 2, pp. 124-134, (in Russian).

Sayfutdinova, GB 2017, 'The main trends in family and parenthood development in modern Russia', Aktual'nyye problemy gumanitarnykh i yestestvennykh nauk, no. 3-2, pp. 95-97, (in Russian).

Studitskikh, VV 2011, 'Institution of parenthood and its influence on the development of the personality of the child in the traditional culture of the Udmurts', Yezhegodnik finno-ugorskikh issledovaniy, no. 2, pp. 96-102, (in Russian). 